Article

\title{
Plasma Treatment of Ovarian Cancer Cells Mitigates Their Immuno-Modulatory Products Active on THP-1 Monocytes
}

\author{
Sander Bekeschus ${ }^{1, *(\mathbb{D})}$, Can Pascal Wulf ${ }^{1,2}$, Eric Freund ${ }^{1,2}$, Dominique Koensgen ${ }^{2}$, \\ Alexander Mustea ${ }^{2}$, Klaus-Dieter Weltmann ${ }^{1}$ and Matthias B. Stope ${ }^{3}$ \\ 1 ZIK plasmatis, Leibniz Institute for Plasma Science and Technology, 17489 Greifswald, Germany; \\ can.wulf@yahoo.de (C.P.W.); eric.freund@inp-greifswald.de (E.F.); weltmann@inp-greifswald.de (K.-D.W.) \\ 2 Department of Gynaecology and Obstetrics, University Medical Center Greifswald, 17475 Greifswald, \\ Germany; koensgen@uni-greifswald.de (D.K.); alexander.mustea@uni-greifswald.de (A.M.) \\ 3 Department of Urology, University Medical Center Greifswald, 17475 Greifswald, Germany; \\ stopem@uni-greifswald.de \\ * Correspondence: sander.bekeschus@inp-greifswald.de; Tel.: +49-3834-554-3948
}

Received: 1 August 2018; Accepted: 14 September 2018; Published: 15 September 2018

\begin{abstract}
Cancers modulate their microenvironment to favor their growth. In particular, monocytes and macrophages are targeted by immuno-modulatory molecules installed by adjacent tumor cells such as ovarian carcinomas. Cold physical plasma has recently gained attention as innovative tumor therapy. We confirmed this for the OVCAR-3 and SKOV-3 ovarian cancer cell lines in a caspase 3/7 independent and dependent manner, respectively. To elaborate whether plasma exposure interferes with their immunomodulatory properties, supernatants of control and plasma-treated tumor cells were added to human THP-1 monocyte cultures. In the latter, modest effects on intracellular oxidation or short-term metabolic activity were observed. By contrast, supernatants of plasma-treated cancer cells abrogated significant changes in morphological and phenotypic features of THP- 1 cells compared to those cultured with supernatants of non-treated tumor cell counterparts. This included cell motility and morphology, and modulated expression patterns of nine cell surface markers known to be involved in monocyte activation. This was particularly pronounced in SKOV-3 cells. Further analysis of tumor cell supernatants indicated roles of small particles and interleukin 8 and 18, with MCP1 presumably driving activation in monocytes. Altogether, our results suggest plasma treatment to alleviate immunomodulatory secretory products of ovarian cancer cells is important for driving a distinct myeloid cell phenotype.
\end{abstract}

Keywords: kINPen; plasma medicine; tumor immunology; ovarian cancer

\section{Introduction}

In the field of plasma medicine, cells and tissues are exposed to partially ionized gas plasma for therapeutic effects [1]. Cold physical plasmas operated at body temperature (i.e., cause no thermal damage) and are potentially bio-active through a number of components generated including reactive oxygen and nitrogen species (ROS/RNS), ions and electrons, ultraviolet (UV) radiation, and electrical fields. Over the last two decades, potential applications have extended from eradicating microorganisms during wound healing to inactivating tumor cells [2]. Today, effective killing of the latter has been demonstrated for different types of cancers including head and neck [3-5], leukemia [6-8], glioblastoma [9-11], pancreas [12-14], malignant melanoma [15-17], colon [18-20], prostate [21-23], osteosarcoma [24-26], and ovarian [27-29]. It has been established the ROS/RNS are the main drivers of antitumor plasma effects [30-32]. 
With 161,100 deaths worldwide in 2015 and a 5-year survival rate of 45\%, ovarian cancer ranks 8 th in the list of deaths from cancer [33]. The peritoneum of ovarian cancer patients is characterized by an influx of immune cells including monocytes and macrophages [34]. The presence of macrophages also characterizes the bulk tumor [35], presumably due to the early recruitment of monocytes from the blood [36]. As in other tumor types, macrophages are skewed by ovarian cancer cells towards a tumor-supporting phenotype that provides growth factors and fosters angiogenesis [37]. Tumor-associated macrophages (TAMs) are closely associated with hypoxic tumor lesions [38]. ROS can reprogram TAMs to a more inflammatory macrophage phenotype. This illustrates the importance of the tumor cell-monocyte/macrophage axis as potential therapeutic target [39].

Soluble mediators derived from malignant as well as non-malignant cells dictate the inflammatory status within the tumor microenvironment, myeloid differentiation responses, and the level of peritoneal inflammation key in the metastasis of ovarian cancer [40-42]. Using cold physical plasma as potent source of ROS for ovarian cancer cell inactivation, here we investigated the immunomodulatory role of their secretion products in human THP-1 monocytes. Using the two cancer cell lines OVCAR-3 and SKOV-3, we were able to demonstrate that plasma treatment, at least in part, reverted a tumor cell-induced monocyte/macrophage phenotype.

\section{Materials and Methods}

\subsection{Cell Culture, Plasma Treatment, and Supernatants}

The human ovarian cancer cell lines OVCAR-3 (ATCC HTB-161) and SKOV-3 (HTB-77) as well as human THP-1 monocytes (ATCC TIB-202) were maintained in Roswell Park Memorial Medium (RPMI) supplemented with $2 \%$ glutamine, $1 \%$ penicillin/streptomycin, and 10\% FCS (all Sigma, Taufkirchen, Germany). For plasma treatment of ovarian cancer cell lines, $2 \times 10^{5}$ cells were suspended in $500 \mu \mathrm{L}$ of fully supplemented medium and added to 24-well plates (Eppendorf, Hamburg, Germany). Cells were exposed for $30 \mathrm{~s}$ to cold physical plasma of the atmospheric pressure plasma jet kINPen (neoplas, Greifswald, Germany) with argon (air liquid, Paris, France) as feed gas at a flux of four standard liters per minute. Control cells were left untreated or exposed to argon gas alone for $30 \mathrm{~s}$. After $4 \mathrm{~h}$ of incubation, supernatants of several wells pooled, centrifuged at $1000 \times g$ for 5 min to eradicate any remaining cells, and stored at $-20^{\circ} \mathrm{C}$ until further use. THP- 1 cells were not directly exposed to plasma in this study. Instead, they were cultured either in fully supplemented medium or in fully supplemented medium containing supernatants of control or plasma-treated ovarian cancer cells ( $80 \mu \mathrm{L}$ of medium or supernatants with $20 \mu \mathrm{L}$ of THP- 1 cell suspension). $1 \times 10^{4}$ THP- 1 cells were cultured in 96-well plates (Eppendorf) with a water-filled rim to prevent evaporation during incubation for up to $96 \mathrm{~h}$. An extra of $50 \mu \mathrm{L}$ cell culture medium was added to THP-1 cells after $48 \mathrm{~h}$ for long-term cultures.

\subsection{Metabolic Activity and Viability of Ovarian Cancer Cells}

To assess metabolic activity of ovarian cancer cells after plasma treatment they were incubated with resazurin (Alfa Aesar, Haverhill, MA, USA) at a final concentration of $100 \mu \mathrm{M}$. After $4 \mathrm{~h}$ of incubation, supernatants were transferred to a flat-bottom 96-well plate. Fluorescence was assessed using a microplate reader (Tecan, Männedorf, Switzerland) at $\lambda_{\mathrm{ex}} 535 \mathrm{~nm}$ and $\lambda_{\mathrm{em}} 590 \mathrm{~nm}$, and normalized to that of untreated control cells. For apoptosis at $4 \mathrm{~h}$, cells were incubated with caspase 3/7 reagent (life technologies, Darmstadt, Germany) and 4',6-Diamidin-2-phenylindol (DAPI, Sigma) for $15 \mathrm{~min}$. Subsequently, cells were harvested and caspase and DAPI fluorescence was measured at a single-cell level using flow cytometry (CytoFlex; Beckman-Coulter, Brea, CA, USA). For time resolved cell death analysis, $\mathrm{DAPI}^{+}$cells were quantified over a time course of $4 \mathrm{~h}$ using fluorescence microscopy. 


\subsection{High Content Imaging of THP-1 Monocytes}

Imaging experiments were performed using an Operetta CLS high content imaging device (PerkinElmer, Hamburg, Germany), and analyzed with Harmony 4.6 software (PerkinElmer). To investigate motility of THP-1 cells, time-lapse video microscopy was performed at a 15 min interval for $4 \mathrm{~h}$. Cells were segmented, boarder objects were removed, and tracking kinetics for individual cells were calculated. For calculation of mean cell-based cytosolic area, imaging was performed using digital phase contrast at $24 \mathrm{~h}$. Phorbol-12-myristat-13-acetat (PMA; Sigma) at a final concentration of $100 \mathrm{nM}$ served as positive control. To generate a morphometric analysis of THP-1 cells, segmented objects were analyzed using the software-specific SER HOLE feature that allows texture-based read out of pixel distributions in the bright field channel at $24 \mathrm{~h}$ in one experiment. For all types of quantitative image analysis, 9-36 fields of views (FoV) were acquired for each of three to six technical replicates per condition. The sum of segmentation-based object count in these FoV was, depending on the assay type and incubation time, approximately 500-3000 that was used to generate mean values for the respective analysis. Approximately 4000 images were analyzed in this study.

\subsection{Metabolic Activity and Flow Cytometry of THP-1 Monocytes}

Metabolic activity of THP-1 cells cultured with or without tumor cell supernatants was assessed at $24 \mathrm{~h}$ following a $4 \mathrm{~h}$ incubation period with resazurin as described above for ovarian cancer cells. Total cell counts were retrieved by flow cytometry (CytoFlex) at $24 \mathrm{~h}$. To detect immediate oxidative effects THP-1 cells, the latter were stained with hydroxyphenyl fluorescein (HPF) and mitotracker orange (MTO), or CM- $\mathrm{H}_{2}$-DCF-DA (DCF; all life technologies) as well as DAPI prior to exposure to tumor culture supernatants. This specific mitotracker dye only accumulates in cells with intact mitochondrial membrane potential $(\Delta \Psi \mathrm{m})$. Thereafter, mean fluorescence intensities in viable (DAPI-negative) cells were assessed by flow cytometry, and normalized to that of THP- 1 cells, which had received fully supplemented culture medium only. Hydrogen peroxide $\left(\mathrm{H}_{2} \mathrm{O}_{2}\right)$ served as positive control for DCF staining. Cell surface marker analysis was performed at 96. For this, THP-1 cell culture medium was collected and any remaining THP-1 cells attaching to the plastic bottom of the 96-well plate were detached and added to the respective matching tube. Cells were washed with phosphate-buffered saline (PBS; Sigma) and incubated for $15 \mathrm{~min}$ in the dark with fluorochrome-labelled antibodies targeted against the following surface markers: CD15s (PerCP Cy5.5), CD33 (BV510), CD41 (Pacific Blue), CD45RA (PE-Dazzle), CD49d (FITC), CD55 (PE-Cy5), CD63 (PE), CD69 (BV650), CD154 (APC7), CD271 (PE-Cy7), and HLA-ABC (APC) (all BioLegend, London, United Kingdom). PMA served as positive control. After two subsequent washes with PBS, cells were analyzed by 11-color flow cytometry. Only viable cells (with appropriate forward scatter and side scatter properties) were included in the analysis. Gating and compensation was performed using Kaluza analysis software 2.1 (Beckman-Coulter). Approximately 500 individual flow cytometry measurements were included in this study.

\subsection{Supernatant Analysis}

Tumor cell supernatants were stained with Bodipy (life technologies) and analyzed for small particle release by flow cytometry (Gallios, Beckman-Coulter) as previously described [43] in one experiment with several technical replicates. Heat-shock protein 27 (HSP27) was measured using enzyme-linked immunosorbent assay (ELISA, RnD Systems, Wiesbaden, Germany) according to the manufacturer's instructions. Multiplex cytokine analysis of THP-1 (at day 6) and tumor cell supernatants (at $4 \mathrm{~h}$ ) was performed with the LegendPlex bead-array based quantification kit (BioLegend) according to the vendor's instructions. Beads were analyzed by flow cytometry. 5-log logarithmic functions and LegendPlex software 8.0 (Vigenetech, Carlisle, USA) were employed to calculate absolute target concentrations. Several technical replicates of pooled supernatants from at least three independent experiments were used for ELISA and multiplex cytokine analysis. 


\subsection{Statistical Analysis}

For each assay if not indicated otherwise, at least three independent experiments with at least three technical replicates each were performed and included into data analysis. Unpaired student's T-test was employed to compare the effect of argon or plasma treatment to untreated control or to medium control, as well as between untreated and plasma treatment. Prism 7.05 software (GraphPad software, La Jolla, CA, USA) was employed for data calculation (mean and standard error), graphing, and statistical analysis. Level of significance is indicated as follows: $\alpha=0.05\left(^{*}\right), \alpha=0.01\left(^{* *}\right)$, $\alpha=0.001{ }^{(* * *)}$.

\section{Results}

\subsection{Plasma Treatment Abrogated Growth of OVCAR-3 and SKOV-3 Cells}

Before analyzing the effect of supernatants from control and plasma-treated tumor cell on THP-1 cells, the toxic amplitude of the plasma exposure was tested. Four hours after plasma treatment, the metabolic activity of both OVCAR-3 and SKOV-3 cells was significantly reduced compared to untreated control (Figure 1a). Argon gas treatment gave no effect. SKOV-3 cells were significantly more sensitive to plasma treatment than OVCAR-3. To understand the kinetics on cell demise, properties of both cell types was follow by time-lapse fluorescence microscopy (Figure 1b). Terminal cell death $\left(\mathrm{DAPI}^{+}\right.$cells) was increasing with elapsed time and more pronounced in SKOV-3 compared to OVCAR-3 cells. Staining for actives caspases 3 and 7 at $4 \mathrm{~h}$, enzymes eminent in apoptosis induction, we found an increase in apoptotic cells (Figure 1c) with plasma treatment but this was only significant for SKOV-3 but not OVCAR-3 cells (Figure 1d). Nonetheless, OVCAR-3 showed a significant reduction in metabolic activity following plasma treatment. This suggested the caspase assay possibly suffering from extensive background signal as we repeatedly observed high numbers of active caspase $3 / 7$ positive cells in our controls. Having elaborated the impact of plasma in cancer cell death, supernatants were analyzed for their immunomodulatory activity in THP- 1 monocytes, next.

\subsection{Supernatants of Plasma-Treated Ovarian Cancer Cell Lines Modestly Affected THP-1 Monocytes' Oxidative Balance and Metabolic Activity}

As cancer cell supernatants stemmed from plasma-treated cultures, it was important to assess their remaining oxidative potential. For this, we stained THP-1 cells with a redox-sensitive fluorescent dye $\mathrm{CM}-\mathrm{H}_{2} \mathrm{DCF}-\mathrm{DA}$, and tested its responsiveness to hydrogen peroxide (Figure 2a) in a dose-dependent fashion (Figure $2 \mathrm{~b}$ ). Upon culture with supernatants with OVCAR-3 but not SKOV-3 cells, a significant increase was observed as well (Figure $2 \mathrm{c}$ ), although on a much lower scale $(\sim 5 \%)$ compared to lowest positive control (15\%, Figure $2 \mathrm{a})$. These results were replicated using a second fluorescent redox indicator, HPF. For mitotracker orange, which selectively accumulates in mitochondria with intact membrane potential, a small but consistent and significant decrease was observed across all samples compared to vehicle control (but not supernatants of control and plasma-treated tumor cells). In some respect, this suggests that tumor cell supernatants generally were sensed different to vehicle culture medium control by THP-1 cells. As mitochondria are important sites of ATP generation, it was subsequently investigated whether the supernatants affected THP-1 metabolic activity and cell count as well the ratio of both (i.e., metabolic activity per cell). Apart from cell counts with SKOV-3 supernatants, no significant changes were observed between treatments or compared to vehicle control (Figure 2d). In tendency, the supernatants of plasma-treated tumor cells reduced THP-1 metabolic activity. Altogether, having noted changes in intracellular oxidation and subtle difference in metabolic activity and growth in THP-1 cells exposed to tumor cell supernatants, microscopic analysis was performed analyze the cells further. 
(a)

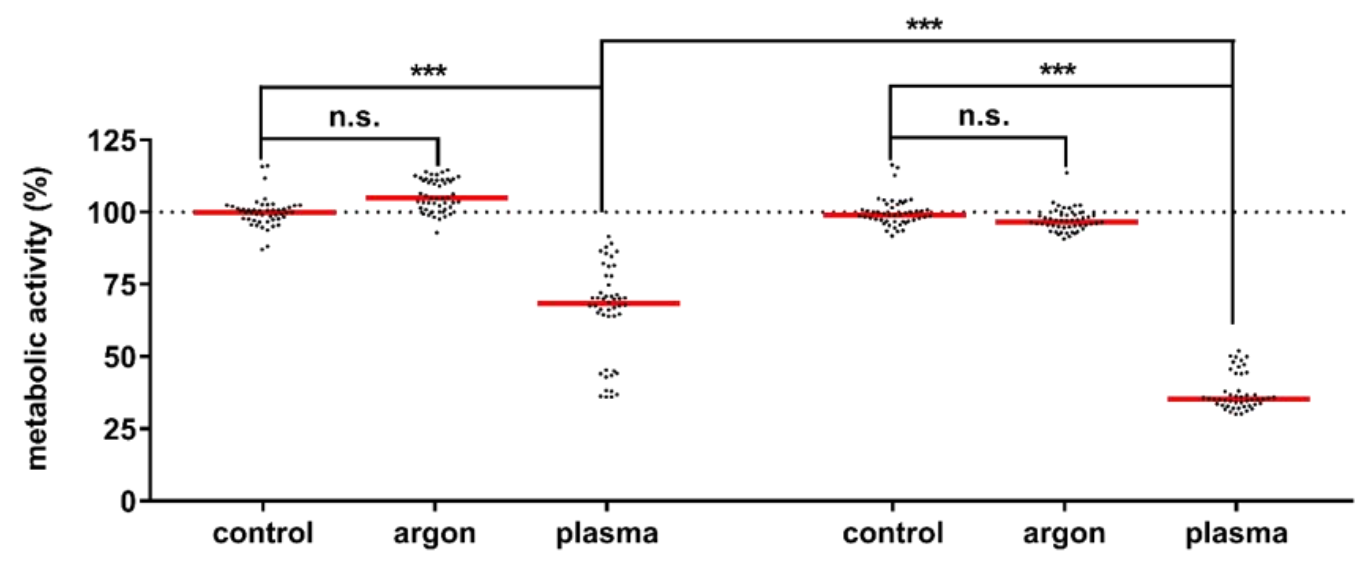

(b)

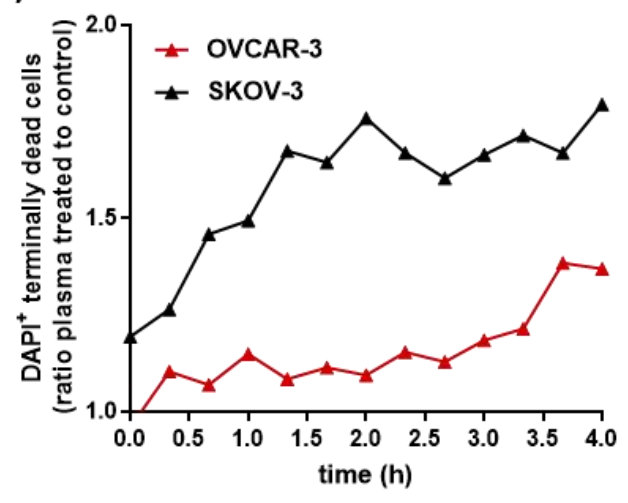

(c)

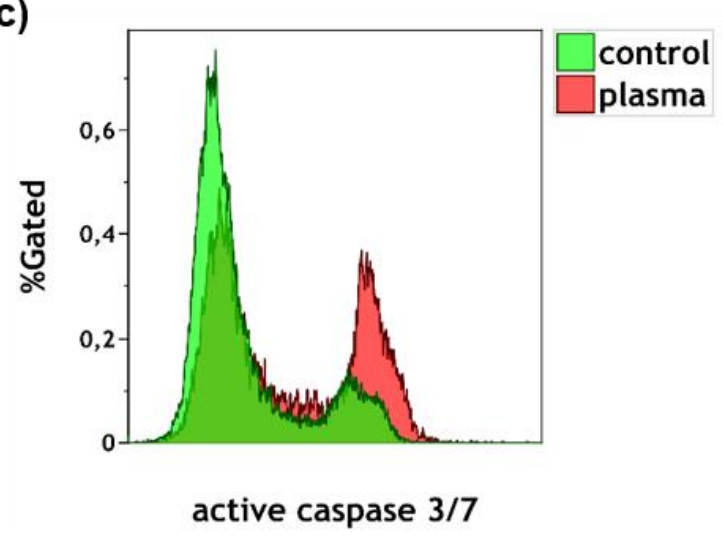

(d)

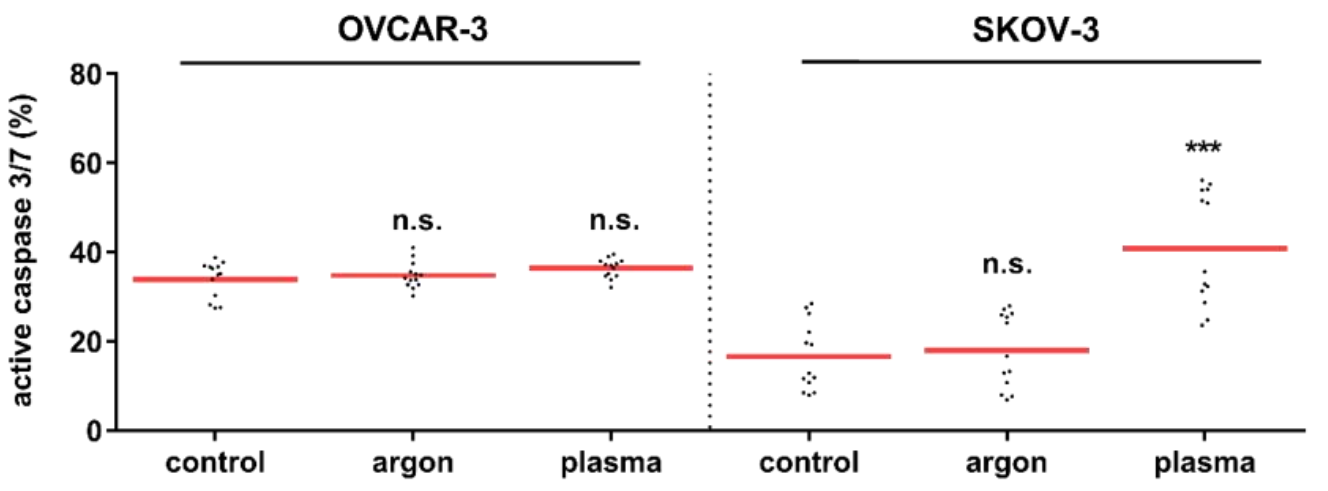

Figure 1. Plasma treatment abrogated growth of OVCAR-3 and SKOV-3 cells. (a) Metabolic activity normalized to that of untreated control cells; (b) ratio of live over dead cells from quantitative images analysis of $4^{\prime}$,6-Diamidin-2-phenylindol $\left(\mathrm{DAPI}^{+}\right)$(terminally dead) cells as assayed via time lapse microscopy; (c) representative fluorescence histogram overlay of untreated control and plasma-treated SKOV-3 cells for active caspases 3 and 7 assayed via flow cytometry; (d) quantification of the percentage of caspase $3 / 7$ positive cells in tumor cells under different conditions. ${ }^{* *}(p<0.001)$ indicates significant difference between indicated samples. 
(a)

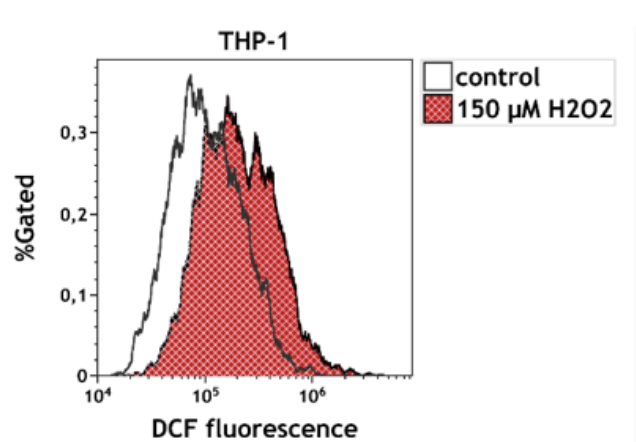

(b)

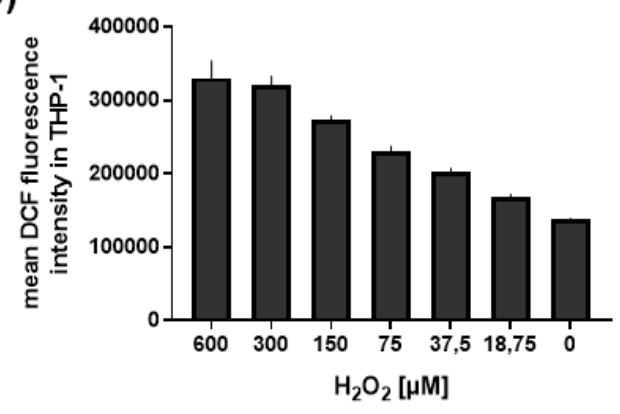

(c)

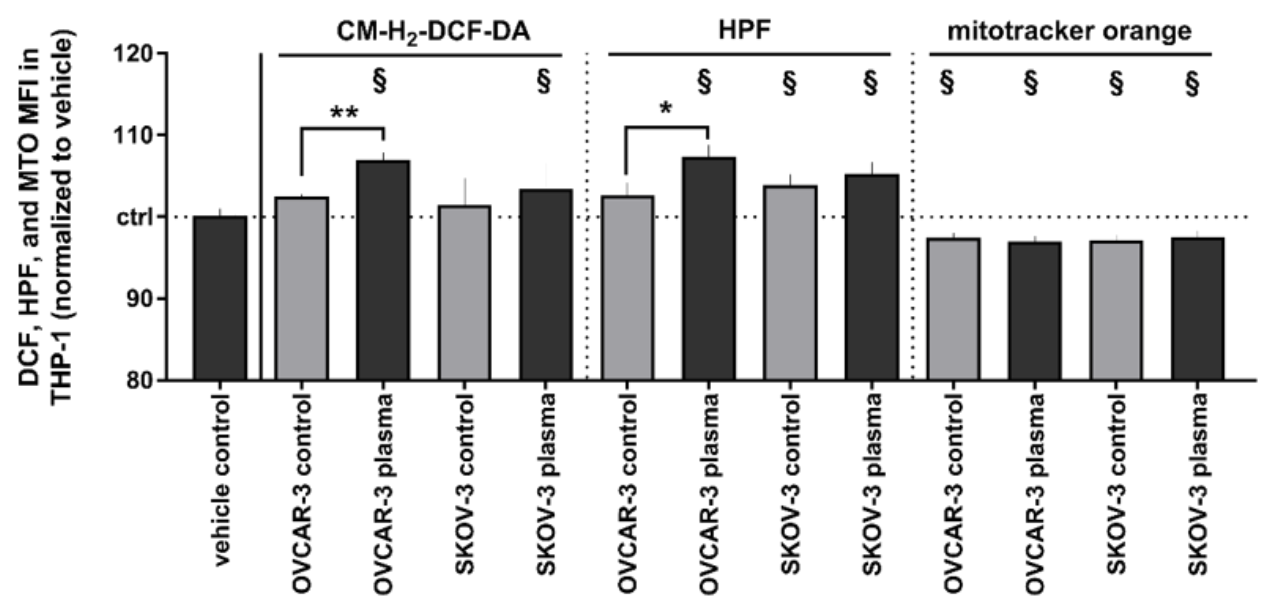

(d)

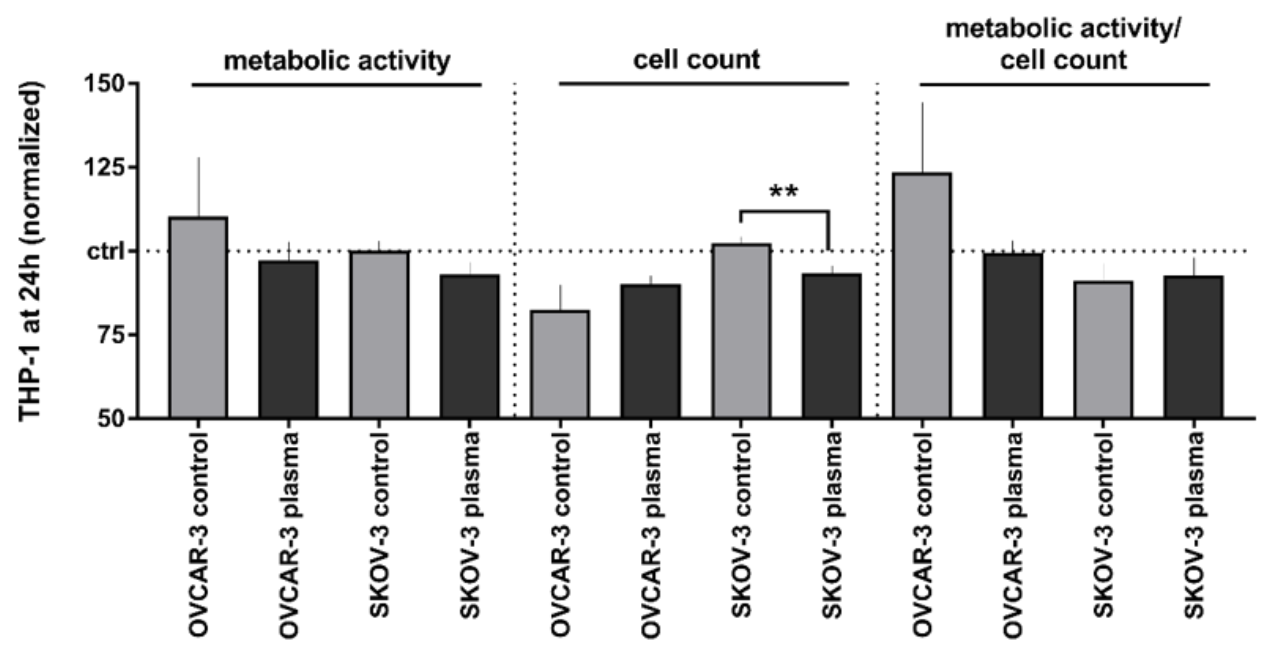

Figure 2. Supernatants of plasma-treated ovarian cancer cell lines modestly affected THP-1 monocytes' oxidative balance and metabolic activity. (a) left: representative fluorescence overlay histogram of control and $\mathrm{H}_{2} \mathrm{O}_{2}$ treated THP-1 cells; (b) quantification of mean DCF fluorescence in a $\mathrm{H}_{2} \mathrm{O}_{2}$ titration series as positive control; (c) quantification of DCF, hydroxyphenyl fluorescein (HPF), and mitotracker orange fluorescence intensities of THP-1 cells cultured with tumor cell supernatants or untreated (vehicle) control medium that served as normalization control; (d) quantification of metabolic activity, cell count, and metabolic activity over cell count ratio in THP-1 cells cultured with tumor cell supernatants at $24 \mathrm{~h}$, each assay was normalized against untreated control medium. $\S$ indicates significant $(p<0.05)$ differences to vehicle control; ${ }^{*}(p<0.05)$ and ${ }^{* *}(p<0.01)$ indicate significant difference between indicated samples. 


\subsection{Plasma Treatment of Ovarian Cancer Cell Lines Alleviated Effects of Their Supernatants on THP-1 Monocyte Motility and Morphology}

Quantitative image analysis is a powerful tool to investigate the morphometric features of cells across a large number of images and individual cells. For tracking the speed of THP-1 monocytes, cells were segmented and tracking tools employed (Figure 3a) to retrieve distance over time data at $4 \mathrm{~h}$. Quantification revealed that supernatants of both OVCAR-3 and SKOV-3 cells decreased cells motility (Figure 3b). Strikingly, plasma-treated supernatants did not do so but rather rescued speed loss back to the level of vehicle control medium. Next, it was assessed whether THP-1 cells co-cultured with tumor cell supernatants displayed morphological features of activated cells. Specifically, non-activated THP-1 cells are round and dense, thus show a high cytosolic intensity when measured with "digital phase contrast" (DPC; Figure 3c, left image). By contrast, activating agents such as PMA lead to a flattening of cells concomitant with a loss of DPC intensity (Figure 3c, right image). Quantification at $24 \mathrm{~h}$ revealed that DPC intensity of THP-1 cells cultured with tumor cell supernatants was not different from that of vehicle control, especially in comparison to positive control PMA (Figure 3d). To perform more detailed visual fingerprinting of THP-1 cells, texture based feature analysis (SER HOLE) was employed in bright field images segmented from DPC intensities (Figure 3e). This allows measuring the intracellular density and distribution quantitatively. The white arrow (Figure 3e) shows a denser cell with the correspondingly different SER HOLE image. Analogously to cell motility measurements (Figure 3b), supernatants of plasma-treated tumor cells alleviated the decrease in SER HOLE intensity seen with control tumor-cell supernatants in THP-1 monocytes at $24 \mathrm{~h}$ (Figure 3f). In summary, we observed effects of tumor cell supernatants on THP-1 cells motility and morphology, which was reduced to vehicle control levels with plasma-treated supernatants.

\subsection{Plasma Treatment of SKOV-3 Cells Mitigated Effects of Their Supernatants on THP-1 Monocyte Surface Marker Expression}

Cell surface marker analysis provides a good mean to investigate the activation status of immune cells. We performed a multicolor flow cytometry panel for 11 markers known to be regulated in THP-1 monocyte activation. To validate our approach, we first compared the staining intensity differences between unstained and stained, non-activated cells, which allows assessing baseline marker expression (Figure 4a). Expression of CD41, CD45RA, CD63, and CD69 was weak or absent in resting monocytes. In parallel, we stained PMA-activated monocytes/macrophages and measured marker intensities at $96 \mathrm{~h}$ using flow cytometry. Except for CD49d, all markers investigated were upregulated in THP-1 monocytes/macrophages upon PMA treatment (Figure 4a). These measurements helped in judgement of subsequent data from THP-1 monocytes incubated with tumor cell-derived supernatants (Figure $4 \mathrm{~b}$ ). Neither control nor plasma-treated OVCAR-3 supernatants notably modulated the expression of any of the 11 markers in THP-1 monocytes at $96 \mathrm{~h}$ (Figure 4c). Conversely, control SKOV-3 supernatants upregulated the expression of eight markers also observed with PMA-induced monocyte-to-macrophage differentiation (Figure 4b), although to a lesser degree. Another marker, CD49d was down regulated, similar to PMA samples. Strikingly, this response was diminished when THP-1 monocytes were incubated with plasma-treated SKOV-3 supernatants. These results suggested that plasma treatment mitigates immunomodulatory effects of tumor cell-derived supernatants in THP-1 monocytes. 
(a)

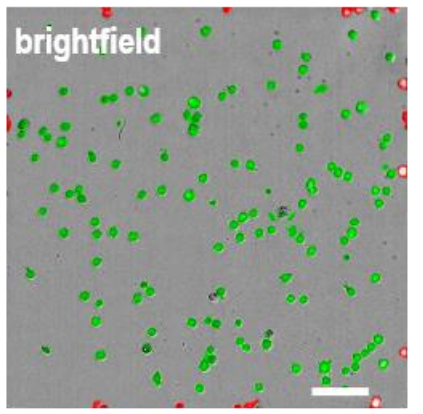

(c)

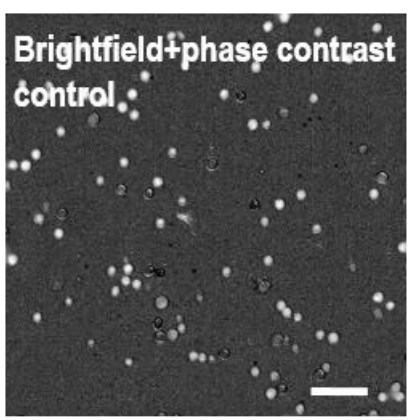

(e)

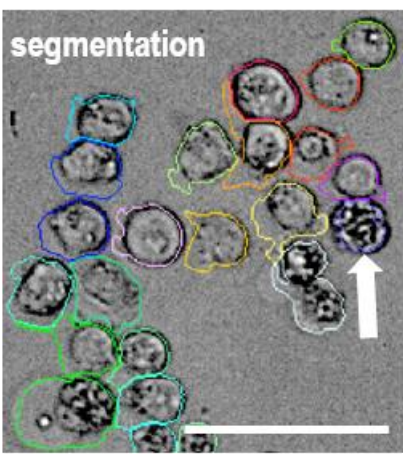

(b)
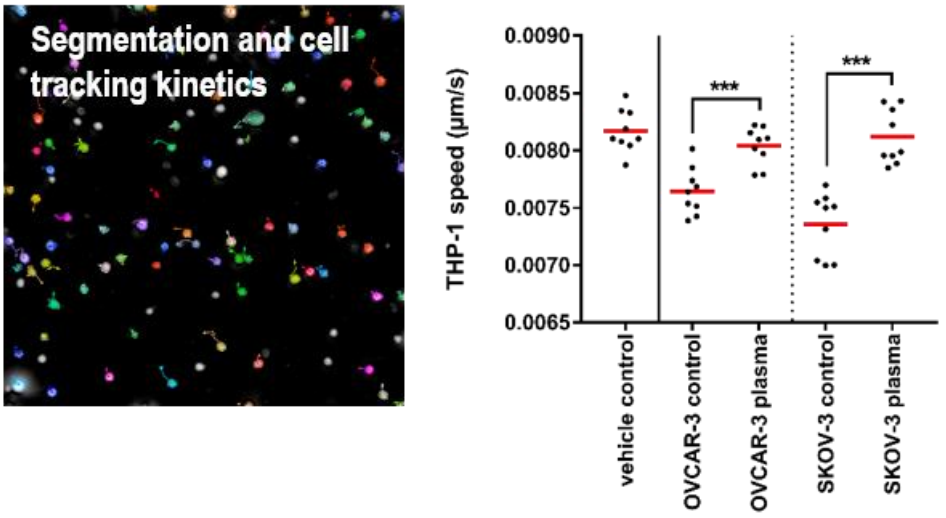

(d)
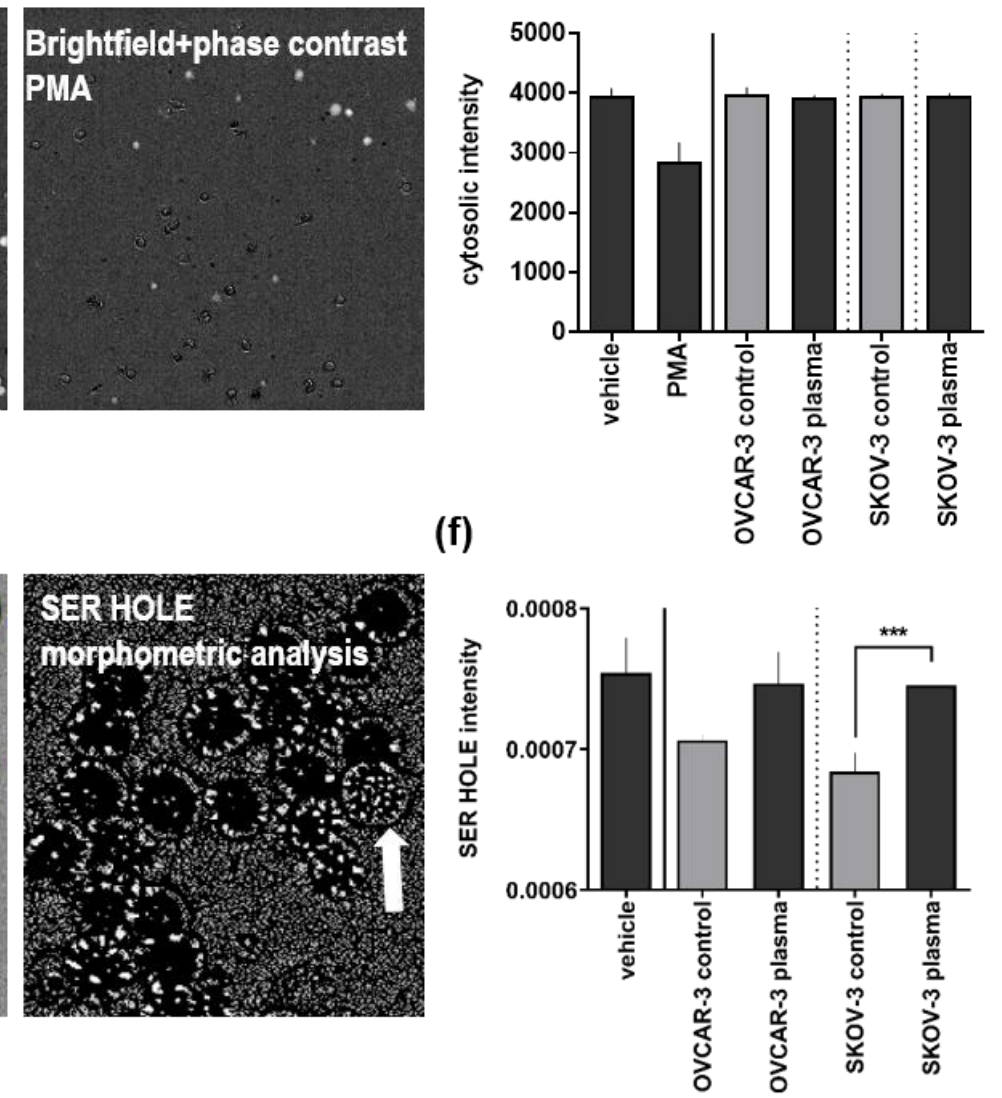

Figure 3. Plasma treatment of ovarian cancer cell lines alleviated effects of their supernatants on THP-1 monocyte motility and morphology. (a) Left: representative bright field image with segmented THP-1 cells (green) and excluded boarder objects (red), right: representative digital phase contrast (DPC) image with individual distance accumulation over $4 \mathrm{~h}$; (b) quantification of tracking distances in THP-1 cells; (c) representative bright field image overlay with DPC of control (left) and PMA-treated (right) THP-1 cells at $24 \mathrm{~h}$, note the decrease in white DPC signal in PMA samples; (d) quantification of cytosolic intensity from DPC images; (e) segmented THP-1 cells in bright field (left) and SER HOLE feature display (right), note the indicated (white arrow) cell with altered morphometric properties (left) that become a quantitative measure by a less empty (hole) area within the cell (right); (f) quantification of SER HOLE intensity. Scale bar $=50 \mu \mathrm{m}$. 
(a)
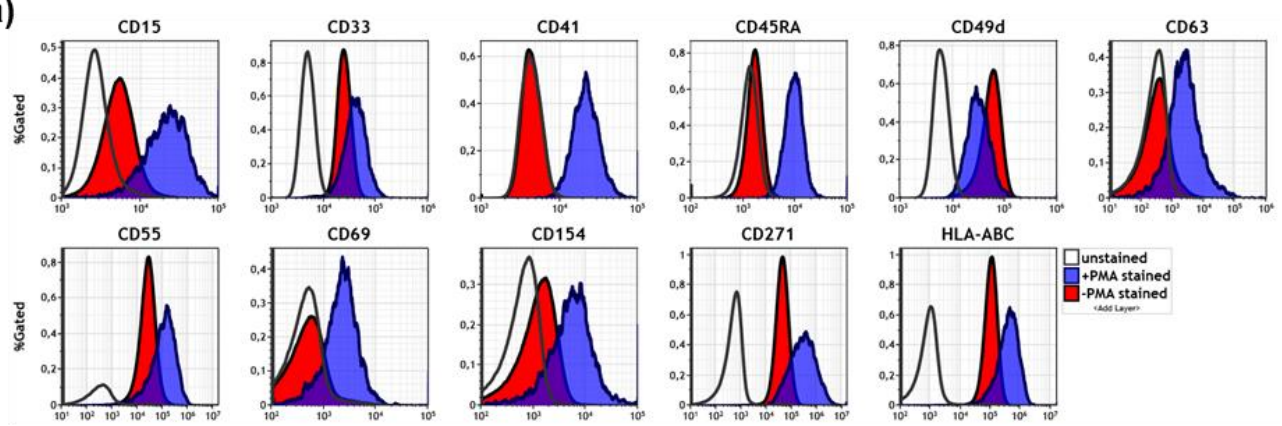

HLA-ABC

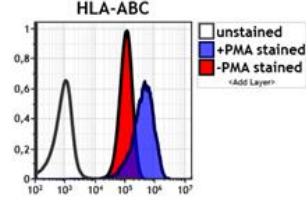

(b)
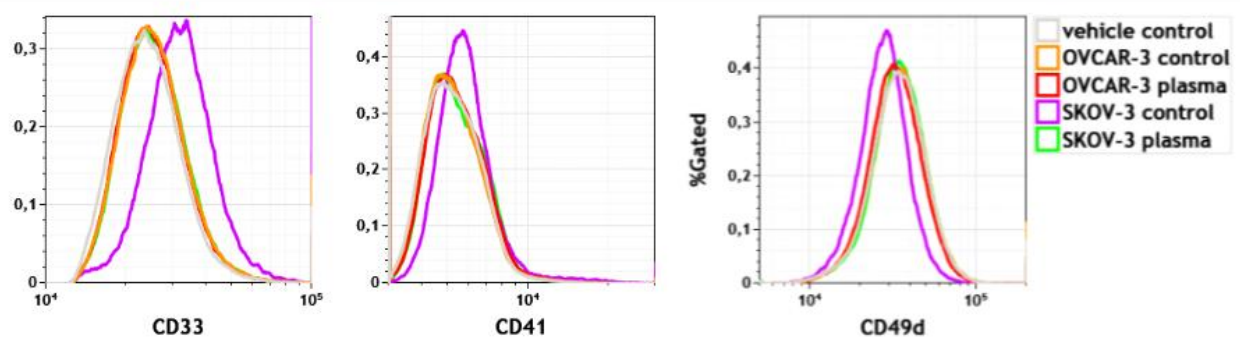

(c)

$100 \%$ = vehicle control

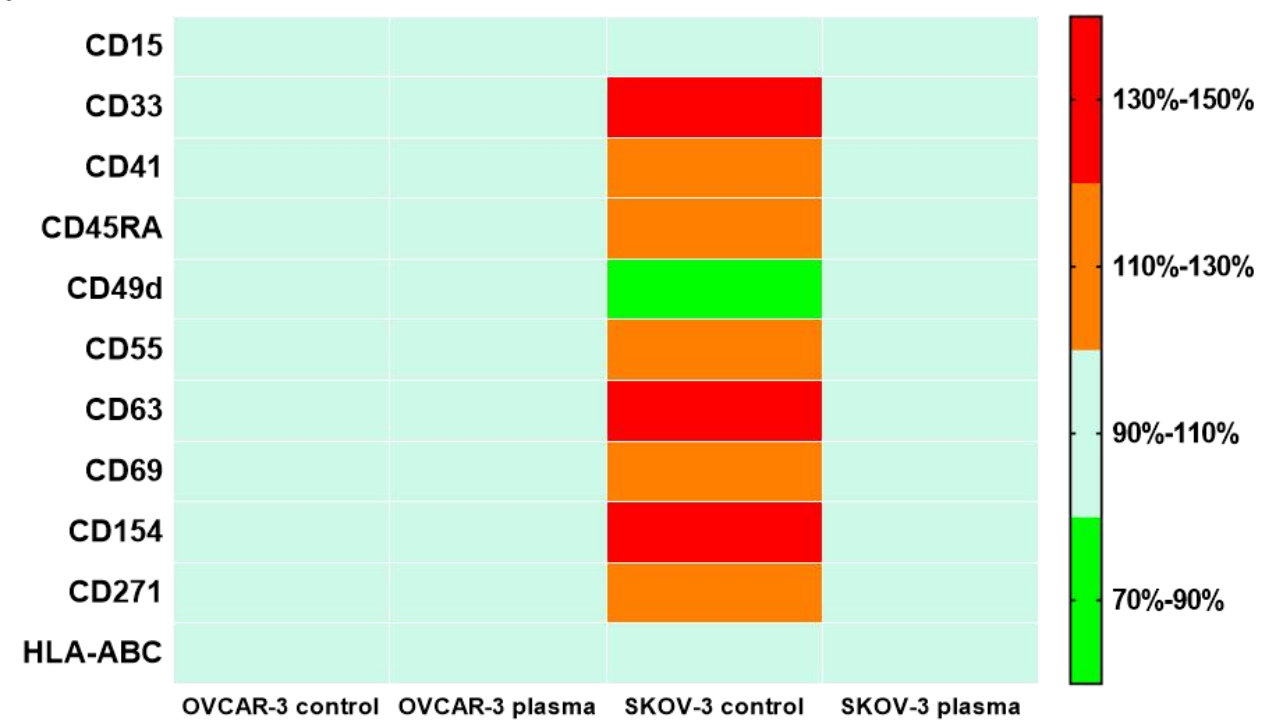

Figure 4. Plasma treatment of SKOV-3 cells mitigated effects of their supernatants on THP-1 monocyte surface marker expression. (a) Representative overlay histograms showing the fluorescence intensity of unstained control (white), stained control (red), and stained PMA-treated (blue) THP-1 cells at 96 h; (b) representative overlay histograms showing the fluorescence intensities of CD33, CD41, and CD49d in THP-1 cells receiving different types of tumor supernatants; (c) summary heat map of fold changes in surface marker expression in THP-1 monocytes with tumor cell supernatants normalized to that of THP-1 cells incubated with vehicle control cell culture medium.

\subsection{Plasma Treatment of Ovarian Cancer Cells Changed Their Secretory Products and Those of THP-1 Cells}

OVCAR-3 and SKOV-3 supernatants modulated THP-1 activity, morphology, and surface marker expression. To screen for potential mediators, we further investigated these supernatants for potentially active mediators. Many cell types, including cancer cells are capable of modifying inflammation via the release of small vesicles or particles budded from the cell's surface such as microparticles, capable of inducing differentiation-like responses in human monocytes [44]. To this end, we analyzed the cell-depleted supernatants of OVCAR-3 and SKOV-3 cells for membrane-containing vesicles by 
staining with a bodipy dye and measuring fluorescence intensities via flow cytometry as established previously [43]. Plasma treatment qualitatively (Figure 5a) and quantitatively (Figure 5b) decreased the total number of small particles (range approximately 400 to $3000 \mu \mathrm{m}$ ) measured at $4 \mathrm{~h}$ in equal liquid volumes. Although the downregulation of small particles may contribute to the effects observed above, we further investigated supernatants for soluble mediators principally released by tumor cells and known to modulate myeloid cell activity, such as heat shock protein 27 (HSP27) [45]. Plasma treatment profoundly increased the amount of HSP27 in supernatants of OVCAR-3 but not SKOV-3 cells (Figure 5c). As these results did not explain the responses seen in THP- 1 monocytes, we performed a 13-plex cytokine screening in supernatants of control and plasma-treated tumor cells at $4 \mathrm{~h}$ as well as THP-1 monocyte supernatants cultured for $96 \mathrm{~h}$ in vehicle, control, or plasma-treated tumor cell supernatants (Table 1). In tumor cell supernatants, many analytes were not detected with IL8 being the only strongly expressed chemokine/cytokine found. It was upregulated with plasma treatment, similar to IL18 and TNF $\alpha$, although to a much lesser extent and only in OVCAR-3 cells. For THP-1 monocytes, only IL8, IL18, and MCP1 were detected. IL8 was absent in vehicle controls but measurable in all samples that have received tumor cell supernatants, possible as endogenous response to the same or as remaining molecules originally stemming from ovarian cancer cells. IL18 was significantly decreased in THP-1 monocytes receiving plasma-treated compared to control OVCAR-3 supernatants, despite the reverse release pattern found in OVCAR-3 supernatants alone. This suggest a THP-1-dependent regulation of IL18 but does not explain the results observed in cell surface marker analysis (Figure 4c). By contrast, MCP1 levels strongly reflected the findings with surface marker expression patterns in monocytes. Levels in supernatants of THP-1 cells receiving vehicle control medium, or control or plasma-treated OVCAR-3 supernatants were similar. Control supernatants of SKOV-3 cells gave a 4 -fold increased release in THP-1 cells but a significant decline to vehicle control levels with plasma-treated SKOV-3 supernatants. In summary, reduced amounts of small particles and/or an unknown immunomodulator in ovarian cancer cell supernatants may explain a suggested MCP1-driven activation response in human THP-1 monocytes.

(a)

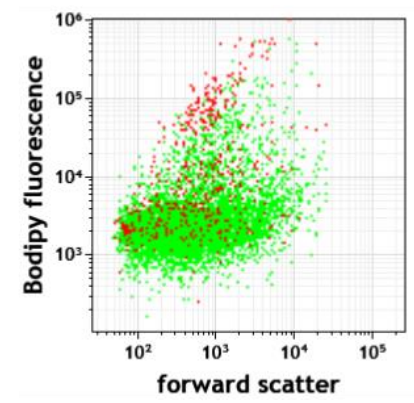

(b)

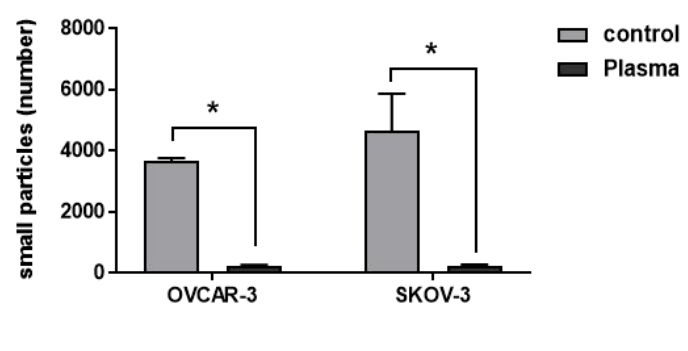

(c)

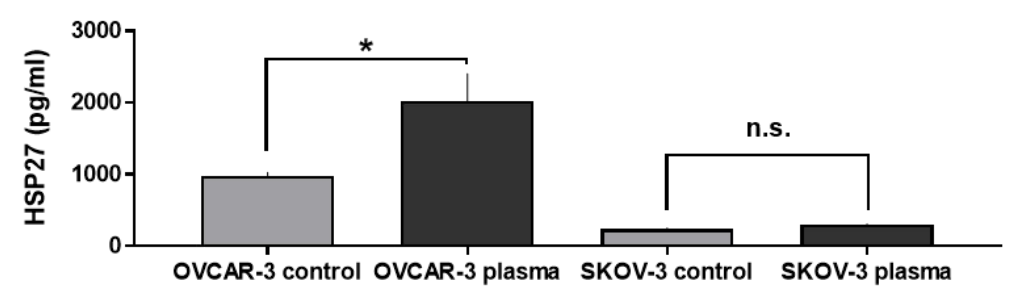

Figure 5. Plasma treatment of ovarian cancer cells changed their secretory products. (a) Representative bivariate dot plot of noise-discriminated small particles in the supernatants of control (green) and plasma-treated (red) OVCAR-3 cells at $4 \mathrm{~h}$; (b) absolute quantification of small particles present in $5 \mu \mathrm{L}$ of supernatant; (c) quantification of heat-shock-protein 27 (HSP27). 
Table 1. 13-plex cytokine analysis of cell culture supernatants retrieved in this study.

\begin{tabular}{|c|c|c|c|c|c|c|c|c|c|c|}
\hline \multicolumn{2}{|c|}{ Sample Source } & \multicolumn{5}{|c|}{ THP-1 Monocyte Supernatants } & \multicolumn{2}{|c|}{ OVCAR-3 Supernatants } & \multicolumn{2}{|c|}{ SKOV-3 Supernatants } \\
\hline Target & Statistic & Vehicle & Ov-Ctrl & Ov-P1 & Sk-Ctrl & Sk-Pl & Ctrl & P1 & Ctrl & P1 \\
\hline \multirow{2}{*}{$\operatorname{IL1} \beta$} & Mean & 2.5 & 2.5 & 2.5 & 2.5 & 2.5 & 2.5 & 2.5 & 2.5 & 2.5 \\
\hline & S.D. & 0.0 & 0.0 & 0.0 & 0.0 & 0.0 & 0.0 & 0.0 & 0.0 & 0.0 \\
\hline \multirow{2}{*}{ IL8 } & Mean & 2.1 & 40.2 & $2.7 * * *$ & 18.6 & 3.6 & 133.3 & 280.1 & 33.8 & $69.1 * *$ \\
\hline & S.D. & 0.0 & 0.9 & 0.8 & 28.6 & 2.6 & 59.4 & 99.1 & 6.8 & 9.6 \\
\hline \multirow{2}{*}{ IL10 } & Mean & 1.2 & 1.2 & 1.2 & 1.2 & 1.2 & 1.2 & 1.2 & 1.2 & 1.2 \\
\hline & S.D. & 0.0 & 0.0 & 0.0 & 0.0 & 0.0 & 0.0 & 0.0 & 0.0 & 0.0 \\
\hline \multirow{2}{*}{ IL12p70 } & Mean & 1.3 & 1.3 & 1.3 & 1.3 & 1.3 & 1.3 & 1.3 & 1.3 & 1.3 \\
\hline & S.D. & 0.0 & 0.0 & 0.0 & 0.0 & 0.0 & 0.0 & 0.0 & 0.0 & 0.0 \\
\hline \multirow{2}{*}{ IL17 } & Mean & 4.2 & 4.2 & 4.2 & 4.2 & 4.2 & 4.2 & 4.2 & 4.2 & 4.2 \\
\hline & S.D. & 0.0 & 0.0 & 0.0 & 0.0 & 0.0 & 0.0 & 0.0 & 0.0 & 0.0 \\
\hline \multirow{2}{*}{ IL18 } & Mean & 3.5 & 7.9 & $2.7 * *$ & 2.0 & 2.2 & 7.1 & $29.5 *$ & 1.3 & 1.3 \\
\hline & S.D. & 1.4 & 0.4 & 0.9 & 1.2 & 0.8 & 3.0 & 8.4 & 0.0 & 0.0 \\
\hline \multirow{2}{*}{ IL23 } & Mean & 3.4 & 3.4 & 3.4 & 3.4 & 3.4 & 3.4 & 3.4 & 3.4 & 3.4 \\
\hline & S.D. & 0.0 & 0.0 & 0.0 & 0.0 & 0.0 & 0.0 & 0.0 & 0.0 & 0.0 \\
\hline \multirow{2}{*}{ IL33 } & Mean & 3.0 & 3.0 & 3.0 & 3.0 & 3.0 & 3.0 & 3.0 & 3.0 & 3.0 \\
\hline & S.D. & 0.0 & 0.0 & 0.0 & 0.0 & 0.0 & 0.0 & 0.0 & 0.0 & 0.0 \\
\hline \multirow{2}{*}{$\operatorname{IFN} \alpha$} & Mean & 0.7 & 0.7 & 0.7 & 0.7 & 0.7 & 0.7 & 0.7 & 0.7 & 0.7 \\
\hline & S.D. & 0.0 & 0.0 & 0.0 & 0.0 & 0.0 & 0.0 & 0.0 & 0.0 & 0.0 \\
\hline \multirow{2}{*}{$\mathrm{IFN} \gamma$} & Mean & 2.7 & 2.7 & 2.7 & 2.7 & 2.7 & 2.7 & 2.7 & 2.7 & 2.7 \\
\hline & S.D. & 0.0 & 0.0 & 0.0 & 0.0 & 0.0 & 0.0 & 0.0 & 0.0 & 0.0 \\
\hline \multirow{2}{*}{ MCP1 } & Mean & 12.2 & 14.1 & 17.3 & 44.5 & $13.6 * * *$ & 3.1 & 3.1 & 3.1 & 3.1 \\
\hline & S.D. & 2.7 & 3.2 & 3.1 & 2.3 & 2.3 & 0.0 & 0.0 & 0.0 & 0.0 \\
\hline TNF $\alpha$ & Mean & 1.7 & 1.7 & 1.7 & 1.7 & 1.7 & 1.7 & $4.7^{* *}$ & 1.7 & 1.7 \\
\hline
\end{tabular}

IL: interleukin; IFN: interferon; MCP1: monocyte-chemoattractant protein 1 (CCL2); S.D.: standard deviation; Ov: OVCAR-3; Sk: SKOV-3; Ctrl: control; Pl: plasma; ${ }^{*}(p<0.05)$, ${ }^{* *}(p<0.01)$, and ${ }^{* * *}(p<0.001)$ mark significant differences to the respective control of the matching supernatant and/or cell type. 


\section{Discussion}

Monocyte education and macrophage polarization by ovarian cancer cells is key in tumor progression. Cold physical plasma has been suggested for cancer treatment, and we investigated the impact of secretory products of ovarian cancer cells in human THP-1 monocytes in the context of plasma.

Several lines of evidence argued for THP-1 immunomodulation or possibly activation by ovarian cancer cell supernatants. A decrease in mitochondrial membrane potential as well as an increase in ROS was observed, which is associated with inflammasome-mediated THP-1 cell activation [46]. Moreover, a change in motility and morphological features was observed, events known from earlier studies with THP-1 activation [47]. This was concomitant with a change in surface marker expression patterns at $96 \mathrm{~h}$, although only in one of four supernatant conditions investigated. Possibly, early activation events by tumor cell supernatants were abrogated during long culture conditions for the remaining three. However, we could not identify morphological features at $96 \mathrm{~h}$ to confirm findings by flow cytometry as high cell densities at $96 \mathrm{~h}$ hampered quantitative image analysis. Cytokine patterns (increase in IL8, IL18, and MCP1 compared to vehicle control) reflected an immunomodulation in THP-1 cells cultured in tumor cell supernatants as well. IL18 is marker of inflammasome activation in THP-1 cells [48], while lipopolysaccharide-stimulated THP-1 monocytes secrete IL8 [49] and MCP1 [50]. IL8 is also released in response to oxidative stimuli [51]. The absence of IL1 $\beta$ and TNF $\alpha$ is in line with findings in primary monocyte-derived macrophages [52]. Although the amplitude of total chemokine/cytokine secretion was rather low, there was a striking similarity between MCP1 release and flow cytometry surface marker profiles. MCP1 is a potent chemoattractant and activator for monocytes [53]. As this chemokine was not present in tumor cell supernatants, we speculate that MCP1 activated THP-1 monocytes in a paracrine or autocrine fashion in response to SKOV-3-derived secretory products.

There are several possibilities for immunomodulatory agents in tumor cell supernatants that, alone or in concert with plasma treatment, could have acted on THP-1 monocytes. A subtle, yet consistent increase in intracellular THP-1 cell oxidation was seen with tumor cell supernatants and elevated in plasma conditions. For the latter, it is tempting to speculate that this finding is owed to remaining plasma-derived reactive species [54] in the supernatants. However, the kINPen generates approximately $60 \mu \mathrm{M}$ of hydrogen peroxide $\left(\mathrm{H}_{2} \mathrm{O}_{2}\right)$ within $30 \mathrm{~s}$ of plasma treatment of $500 \mu \mathrm{L}$ medium [55,56]. With 200,000 cells suspended in the medium, it is unlikely that significant amounts of $\mathrm{H}_{2} \mathrm{O}_{2}$ would not have reacted with tumor cells across $4 \mathrm{~h}$ of incubation $37{ }^{\circ} \mathrm{C}$ and after freeze-thawing of the supernatants. Instead, it is possible that remaining ROS were secondary derivatives of tumor cells, possibly as active response to stress [57] or as ROS leaking from damaged mitochondria present during apoptosis [58]. Alternatively, ROS increase in THP-1 may have been due to plasma-induced oxidation in biomolecules [59] taken up the cells or immediate activity increase in response to, for instance, chemokines and cytokines. ROS are vital signaling agents observed during activation of monocytes [60], and the subtle but consistent increase in ROS with supernatants of plasma-treated cancer cells may argue for the activation of some THP-1 monocytes. Along similar lines, the subtle but consistent decrease in metabolic activity is associated with activation of monocytes [61]. The levels of IL8 in ovarian cancer supernatants were reasonably high and followed the pattern of ROS in THP-1 monocytes. As IL8 is known to activate monocytes [62], it is reasonable to speculate on its prime role in mediating immediate changes. The decrease of IL8 in plasma-treated supernatants may also explain the alleviated morphometric responses observed with control tumor cell supernatants. A similar observation was made for tumor-derived small particles such as microparticles. These are known for their immunomodulatory properties [63]. However, their quality (protein or mRNA cargo) and not necessarily quantity governs their physiological impact on other cell types. Another secretory product found in ovarian cancer cells was HSP27 but its release pattern does not correlate to any of the findings in THP-1 monocytes, although it is crucial in macrophage polarization [64]. However, we do not propose finding fully differentiated macrophages in our study but rather propose a principle immunomodulatory function of ovarian cancer cell secretory products in monocytes that can be 
targeted with plasma treatment. The practical implications of these findings are limited but it could be speculated that plasma treatment of micro metastasis within resection margins of ovarian cancer surgery may decrease the tumor cells' ability to educate monocyte for cancer-promoting purposes.

Both OVCAR-3 and SKOV-3 are capable of undergoing caspase-dependent apoptosis $[65,66]$. OVCAR-3 and SKOV-3 cells differentially responded to plasma treatment. While a decrease in metabolic activity and an increase in terminal cell death was present in both lines, apoptosis was only significantly enhanced in plasma-treated SKOV-3 but not OVCAR-3. However, this was due to a high, non-eliminable background cell death when detaching and suspending OVCAR-3 cells. Despite this, plasma treatment was still perceived and translated by OVCAR-3 cells into a biological response, as seen with reduction in metabolic activity, release of HSP27, and modulation of cytokine secretion. In general, both OVCAR-3 and SKOV-3 have permanently active hypoxia-related redox-signaling pathways activated to respond to e.g., plasma-derived oxidants, as high steady-state expression levels of HIF1 $\alpha$ suggests [67]. Although SKOV-3 viability was compromised to a higher extent compared to that of OVCAR-3, the cells' sensitivity towards ionizing radiation-induced cell death is reciprocal to our observation to plasma [68]. In addition, their cell surface marker expression differs to some extent, and SKOV-3 but not OVCAR-3 responds in a highly sensitive way towards platinum-based compounds [69]. Similar to plasma, such compounds are known to evoke oxidative stress [70]. For regular chemotherapeutic agents, SKOV-3 are more resistant compared to OVCAR-3 [71].

Author Contributions: Conceptualization, S.B.; Methodology, S.B. and E.F.; Formal Analysis, S.B., C.P.W., and E.F.; Investigation, C.P.W., and E.F.; Writing-Original Draft Preparation, S.B.; Writing-Review and Editing, D.K., A.M., K.-D.W., and M.B.S.; Supervision, S.B. and M.B.S.; Project Administration, S.B.; Funding Acquisition, S.B. and K.-D.W.

Funding: This research was funded by the German Federal Ministry of Education and Research, grant number 03Z22DN11.

Acknowledgments: The authors gratefully acknowledge technical support by Felix Niessner.

Conflicts of Interest: The authors declare no conflict of interest. The funders had no role in the design of the study; in the collection, analyses, or interpretation of data; in the writing of the manuscript, and in the decision to publish the results.

\section{References}

1. Weltmann, K.D.; von Woedtke, T. Plasma medicine-Current state of research and medical application. Plasma Phys. Control. Fusion 2017, 1, 014031. [CrossRef]

2. Laroussi, M. From killing bacteria to destroying cancer cells: 20 years of plasma medicine. Plasma Process. Polym. 2014, 11, 1138-1141. [CrossRef]

3. Guerrero-Preston, R.; Ogawa, T.; Uemura, M.; Shumulinsky, G.; Valle, B.L.; Pirini, F.; Ravi, R.; Sidransky, D.; Keidar, M.; Trink, B. Cold atmospheric plasma treatment selectively targets head and neck squamous cell carcinoma cells. Int. J. Mol. Med. 2014, 34, 941-946. [CrossRef] [PubMed]

4. Kim, S.Y.; Kim, H.J.; Kang, S.U.; Kim, Y.E.; Park, J.K.; Shin, Y.S.; Kim, Y.S.; Lee, K.; Kim, C.H. Non-thermal plasma induces AKT degradation through turn-on the MUL1 E3 ligase in head and neck cancer. Oncotarget 2015, 6, 33382-33396. [CrossRef] [PubMed]

5. Metelmann, H.-R.; Seebauer, C.; Miller, V.; Fridman, A.; Bauer, G.; Graves, D.B.; Pouvesle, J.-M.; Rutkowski, R.; Schuster, M.; Bekeschus, S.; et al. Clinical experience with cold plasma in the treatment of locally advanced head and neck cancer. Clin. Plasma Med. 2018, 9, 6-13. [CrossRef]

6. Turrini, E.; Laurita, R.; Stancampiano, A.; Catanzaro, E.; Calcabrini, C.; Maffei, F.; Gherardi, M.; Colombo, V.; Fimognari, C. Cold atmospheric plasma induces apoptosis and oxidative stress pathway regulation in t-lymphoblastoid leukemia cells. Oxid. Med. Cell. Longev. 2017. [CrossRef] [PubMed]

7. Wang, C.; Zhang, H.X.; Xue, Z.X.; Yin, H.J.; Niu, Q.; Chen, H.L. The relation between doses or post-plasma time points and apoptosis of leukemia cells induced by dielectric barrier discharge plasma. AIP Adv. 2015. [CrossRef] 
8. Schmidt, A.; Rodder, K.; Hasse, S.; Masur, K.; Toups, L.; Lillig, C.H.; von Woedtke, T.; Wende, K.; Bekeschus, S. Redox-regulation of activator protein 1 family members in blood cancer cell lines exposed to cold physical plasma-treated medium. Plasma Process. Polym. 2016, 13, 1179-1188. [CrossRef]

9. Vandamme, M.; Robert, E.; Lerondel, S.; Sarron, V.; Ries, D.; Dozias, S.; Sobilo, J.; Gosset, D.; Kieda, C.; Legrain, B.; et al. Ros implication in a new antitumor strategy based on non-thermal plasma. Int. J. Cancer 2012, 130, 2185-2194. [CrossRef] [PubMed]

10. Tanaka, H.; Mizuno, M.; Ishikawa, K.; Nakamura, K.; Kajiyama, H.; Kano, H.; Kikkawa, F.; Hori, M. Plasma-activated medium selectively kills glioblastoma brain tumor cells by down-regulating a survival signaling molecule, AKT kinase. Plasma Med. 2011, 1, 265-277. [CrossRef]

11. Koritzer, J.; Boxhammer, V.; Schafer, A.; Shimizu, T.; Klampfl, T.G.; Li, Y.F.; Welz, C.; Schwenk-Zieger, S.; Morfill, G.E.; Zimmermann, J.L.; et al. Restoration of sensitivity in chemo-resistant glioma cells by cold atmospheric plasma. PLoS ONE 2013. [CrossRef] [PubMed]

12. Brulle, L.; Vandamme, M.; Ries, D.; Martel, E.; Robert, E.; Lerondel, S.; Trichet, V.; Richard, S.; Pouvesle, J.M.; Le Pape, A. Effects of a non thermal plasma treatment alone or in combination with gemcitabine in a MIA PaCa2-luc orthotopic pancreatic carcinoma model. PLoS ONE 2012. [CrossRef] [PubMed]

13. Hattori, N.; Yamada, S.; Torii, K.; Takeda, S.; Nakamura, K.; Tanaka, H.; Kajiyama, H.; Kanda, M.; Fujii, T.; Nakayama, G.; et al. Effectiveness of plasma treatment on pancreatic cancer cells. Int. J. Oncol. 2015, 47, 1655-1662. [CrossRef] [PubMed]

14. Liedtke, K.R.; Bekeschus, S.; Kaeding, A.; Hackbarth, C.; Kuehn, J.P.; Heidecke, C.D.; von Bernstorff, W.; von Woedtke, T.; Partecke, L.I. Non-thermal plasma-treated solution demonstrates antitumor activity against pancreatic cancer cells in vitro and in vivo. Sci. Rep. 2017. [CrossRef] [PubMed]

15. Bekeschus, S.; Rodder, K.; Fregin, B.; Otto, O.; Lippert, M.; Weltmann, K.D.; Wende, K.; Schmidt, A.; Gandhirajan, R.K. Toxicity and immunogenicity in murine melanoma following exposure to physical plasma-derived oxidants. Oxid. Med. Cell. Longev. 2017. [CrossRef] [PubMed]

16. Ishaq, M.; Kumar, S.; Varinli, H.; Han, Z.J.; Rider, A.E.; Evans, M.D.; Murphy, A.B.; Ostrikov, K. Atmospheric gas plasma-induced ros production activates TNF-ASK1 pathway for the induction of melanoma cancer cell apoptosis. Mol. Biol. Cell 2014, 25, 1523-1531. [CrossRef] [PubMed]

17. Mizuno, K.; Shirakawa, Y.; Sakamoto, T.; Ishizaki, H.; Nishijima, Y.; Ono, R. Plasma-induced suppression of recurrent and reinoculated melanoma tumors in mice. IEEE Trans. Radiat. Plasma Med. Sci. 2018, 2, 353-359. [CrossRef]

18. Lin, A.G.; Xiang, B.; Merlino, D.J.; Baybutt, T.R.; Sahu, J.; Fridman, A.; Snook, A.E.; Miller, V. Non-thermal plasma induces immunogenic cell death in vivo in murine CT26 colorectal tumors. OncoImmunology 2018, 1-13. [CrossRef]

19. Bekeschus, S.; Mueller, A.; Miller, V.; Gaipl, U.; Weltmann, K.-D. Physical plasma elicits immunogenic cancer cell death and mitochondrial singlet oxygen. IEEE Trans. Radiat. Plasma Med. Sci. 2018, 2, 138-146. [CrossRef]

20. Plewa, J.M.; Yousfi, M.; Frongia, C.; Eichwald, O.; Ducommun, B.; Merbahi, N.; Lobjois, V. Low-temperature plasma-induced antiproliferative effects on multi-cellular tumor spheroids. New J. Phys. 2014. [CrossRef]

21. Hirst, A.M.; Simms, M.S.; Mann, V.M.; Maitland, N.J.; O'Connell, D.; Frame, F.M. Low-temperature plasma treatment induces DNA damage leading to necrotic cell death in primary prostate epithelial cells. Br. J. Cancer 2015, 112, 1536-1545. [CrossRef] [PubMed]

22. Weiss, M.; Gumbel, D.; Hanschmann, E.M.; Mandelkow, R.; Gelbrich, N.; Zimmermann, U.; Walther, R.; Ekkernkamp, A.; Sckell, A.; Kramer, A.; et al. Cold atmospheric plasma treatment induces anti-proliferative effects in prostate cancer cells by redox and apoptotic signaling pathways. PLoS ONE 2015. [CrossRef] [PubMed]

23. Zhunussova, A.; Vitol, E.A.; Polyak, B.; Tuleukhanov, S.; Brooks, A.D.; Sensenig, R.; Friedman, G.; Orynbayeva, Z. Mitochondria-mediated anticancer effects of non-thermal atmospheric plasma. PLoS ONE 2016. [CrossRef] [PubMed]

24. Gumbel, D.; Gelbrich, N.; Napp, M.; Daeschlein, G.; Kramer, A.; Sckell, A.; Burchardt, M.; Ekkernkamp, A.; Stope, M.B. Peroxiredoxin expression of human osteosarcoma cells is influenced by cold atmospheric plasma treatment. Anticancer Res. 2017, 37, 1031-1038. [PubMed] 
25. Tokunaga, T.; Ando, T.; Suzuki-Karasaki, M.; Ito, T.; Onoe-Takahashi, A.; Ochiai, T.; Soma, M.; Suzuki-Karasaki, Y. Plasma-stimulated medium kills trail-resistant human malignant cells by promoting caspase-independent cell death via membrane potential and calcium dynamics modulation. Int. J. Oncol. 2018, 52, 697-708. [CrossRef] [PubMed]

26. Canal, C.; Fontelo, R.; Hamouda, I.; Guillem-Marti, J.; Cvelbar, U.; Ginebra, M.P. Plasma-induced selectivity in bone cancer cells death. Free Radic. Biol. Med. 2017, 110, 72-80. [CrossRef] [PubMed]

27. Koensgen, D.; Besic, I.; Gumbel, D.; Kaul, A.; Weiss, M.; Diesing, K.; Kramer, A.; Bekeschus, S.; Mustea, A.; Stope, M.B. Cold atmospheric plasma (CAP) and CAP-stimulated cell culture media suppress ovarian cancer cell growth-A putative treatment option in ovarian cancer therapy. Anticancer Res. 2017, 37, 6739-6744. [PubMed]

28. Nakamura, K.; Peng, Y.; Utsumi, F.; Tanaka, H.; Mizuno, M.; Toyokuni, S.; Hori, M.; Kikkawa, F.; Kajiyama, H. Novel intraperitoneal treatment with non-thermal plasma-activated medium inhibits metastatic potential of ovarian cancer cells. Sci. Rep. 2017. [CrossRef] [PubMed]

29. Utsumi, F.; Kajiyama, H.; Nakamura, K.; Tanaka, H.; Hori, M.; Kikkawa, F. Selective cytotoxicity of indirect nonequilibrium atmospheric pressure plasma against ovarian clear-cell carcinoma. Springerplus 2014. [CrossRef] [PubMed]

30. Ahn, H.J.; Kim, K.I.; Hoan, N.N.; Kim, C.H.; Moon, E.; Choi, K.S.; Yang, S.S.; Lee, J.S. Targeting cancer cells with reactive oxygen and nitrogen species generated by atmospheric-pressure air plasma. PLOS ONE 2014. [CrossRef] [PubMed]

31. Graves, D.B. The emerging role of reactive oxygen and nitrogen species in redox biology and some implications for plasma applications to medicine and biology. J. Phys. D Appl. Phys. 2012. [CrossRef]

32. Yan, D.; Sherman, J.H.; Keidar, M. Cold atmospheric plasma, a novel promising anti-cancer treatment modality. Oncotarget 2017, 8, 15977-15995. [CrossRef] [PubMed]

33. Wang, H.; Naghavi, M.; Allen, C.; Barber, R.M.; Bhutta, Z.A.; Carter, A.; Casey, D.C.; Charlson, F.J.; Chen, A.Z.; Coates, M.M.; et al. Global, regional, and national life expectancy, all-cause mortality, and cause-specific mortality for 249 causes of death, 1980-2015: A systematic analysis for the global burden of disease study 2015. Lancet 2016, 388, 1459-1544. [CrossRef]

34. Wang, X.; Deavers, M.; Patenia, R.; Bassett, R.L., Jr.; Mueller, P.; Ma, Q.; Wang, E.; Freedman, R.S. Monocyte/macrophage and T-cell infiltrates in peritoneum of patients with ovarian cancer or benign pelvic disease. J. Transl. Med. 2006. [CrossRef]

35. Kawamura, K.; Komohara, Y.; Takaishi, K.; Katabuchi, H.; Takeya, M. Detection of M2 macrophages and colony-stimulating factor 1 expression in serous and mucinous ovarian epithelial tumors. Pathol. Int. 2009, 59, 300-305. [CrossRef] [PubMed]

36. Sica, A.; Larghi, P.; Mancino, A.; Rubino, L.; Porta, C.; Totaro, M.G.; Rimoldi, M.; Biswas, S.K.; Allavena, P.; Mantovani, A. Macrophage polarization in tumour progression. Semin. Cancer Biol. 2008, 18, 349-355. [CrossRef] [PubMed]

37. Takaishi, K.; Komohara, Y.; Tashiro, H.; Ohtake, H.; Nakagawa, T.; Katabuchi, H.; Takeya, M. Involvement of M2-polarized macrophages in the ascites from advanced epithelial ovarian carcinoma in tumor progression via Stat3 activation. Cancer Sci. 2010, 101, 2128-2136. [CrossRef] [PubMed]

38. Henze, A.T.; Mazzone, M. The impact of hypoxia on tumor-associated macrophages. J. Clin. Invest. 2016, 126, 3672-3679. [CrossRef] [PubMed]

39. Sica, A.; Schioppa, T.; Mantovani, A.; Allavena, P. Tumour-associated macrophages are a distinct M2 polarised population promoting tumour progression: Potential targets of anti-cancer therapy. Eur. J. Cancer 2006, 42, 717-727. [CrossRef] [PubMed]

40. Freedman, R.S.; Deavers, M.; Liu, J.; Wang, E. Peritoneal inflammation-A microenvironment for epithelial ovarian cancer (EOC). J. Transl. Med. 2004. [CrossRef] [PubMed]

41. Quail, D.F.; Joyce, J.A. Microenvironmental regulation of tumor progression and metastasis. Nat. Med. 2013, 19, 1423-1437. [CrossRef] [PubMed]

42. Coussens, L.M.; Werb, Z. Inflammation and cancer. Nature 2002, 420, 860-867. [CrossRef] [PubMed]

43. Bekeschus, S.; Moritz, J.; Schmidt, A.; Wende, K. Redox regulation of leukocyte-derived microparticle release and protein content in response to cold physical plasma-derived oxidants. Clin. Plasma Med. 2017. [CrossRef] 
44. Baj-Krzyworzeka, M.; Mytar, B.; Szatanek, R.; Surmiak, M.; Weglarczyk, K.; Baran, J.; Siedlar, M. Colorectal cancer-derived microvesicles modulate differentiation of human monocytes to macrophages. J. Transl. Med. 2016. [CrossRef] [PubMed]

45. Salari, S.; Seibert, T.; Chen, Y.X.; Hu, T.; Shi, C.; Zhao, X.; Cuerrier, C.M.; Raizman, J.E.; O’Brien, E.R. Extracellular HSP27 acts as a signaling molecule to activate NF-kB in macrophages. Cell Stress Chaperones 2013, 18, 53-63. [CrossRef] [PubMed]

46. Zhou, R.; Yazdi, A.S.; Menu, P.; Tschopp, J. A role for mitochondria in NLRP3 inflammasome activation. Nature 2011, 469, 221-225. [CrossRef] [PubMed]

47. Auwerx, J. The human leukemia cell line, THP-1: A multifacetted model for the study of monocyte-macrophage differentiation. Experientia 1991, 47, 22-31. [CrossRef] [PubMed]

48. He, Q.; You, H.; Li, X.-M.; Liu, T.-H.; Wang, P.; Wang, B.-E. HMGB1 promotes the synthesis of pro-IL-1 $\beta$ and pro-IL-18 by activation of $\mathrm{p} 38 \mathrm{MAPK}$ and NF- $\mathrm{KB}$ through receptors for advanced glycation end-products in macrophages. Asian Pac. J. Cancer Prev. 2012, 13, 1365-1370. [CrossRef] [PubMed]

49. Sonoda, Y.; Kasahara, T.; Mukaida, N.; Shimizu, N.; Tomoda, M.; Takeda, T. Stimulation of interleukin-8 production by acidic polysaccharides from the root of panax ginseng. Immunopharmacology 1998, 38, 287-294. [CrossRef]

50. Zhang, M.; Zhao, G.J.; Yin, K.; Xia, X.D.; Gong, D.; Zhao, Z.W.; Chen, L.Y.; Zheng, X.L.; Tang, X.E.; Tang, C.K. Apolipoprotein A-1 binding protein inhibits inflammatory signaling pathways by binding to apolipoprotein A-1 in THP-1 macrophages. Circ. J. 2018, 82, 1396-1404. [CrossRef] [PubMed]

51. Bekeschus, S.; Schmidt, A.; Bethge, L.; Masur, K.; von Woedtke, T.; Hasse, S.; Wende, K. Redox stimulation of human THP-1 monocytes in response to cold physical plasma. Oxid. Med. Cell. Longev. 2016. [CrossRef] [PubMed]

52. Daigneault, M.; Preston, J.A.; Marriott, H.M.; Whyte, M.K.; Dockrell, D.H. The identification of markers of macrophage differentiation in PMA-stimulated THP-1 cells and monocyte-derived macrophages. PLoS ONE 2010. [CrossRef] [PubMed]

53. Sozzani, S.; Molino, M.; Locati, M.; Luini, W.; Cerletti, C.; Vecchi, A.; Mantovani, A. Receptor-activated calcium influx in human monocytes exposed to monocyte chemotactic protein-1 and related cytokines. J. Immunol. 1993, 150, 1544-1553. [PubMed]

54. Jablonowski, H.; von Woedtke, T. Research on plasma medicine-relevant plasma-liquid interaction: What happened in the past five years? Clin. Plasma Med. 2015, 3, 42-52. [CrossRef]

55. Bekeschus, S.; Kolata, J.; Winterbourn, C.; Kramer, A.; Turner, R.; Weltmann, K.D.; Broker, B.; Masur, K. Hydrogen peroxide: A central player in physical plasma-induced oxidative stress in human blood cells. Free Radic. Res. 2014, 48, 542-549. [CrossRef] [PubMed]

56. Bekeschus, S.; Winterbourn, C.C.; Kolata, J.; Masur, K.; Hasse, S.; Broker, B.M.; Parker, H.A. Neutrophil extracellular trap formation is elicited in response to cold physical plasma. J. Leukoc. Biol. 2016, 100, 791-799. [CrossRef] [PubMed]

57. Pelicano, H.; Carney, D.; Huang, P. Ros stress in cancer cells and therapeutic implications. Drug Resist. Updat. 2004, 7, 97-110. [CrossRef] [PubMed]

58. Cai, J.; Jones, D.P. Superoxide in apoptosis. Mitochondrial generation triggered by cytochrome c loss. J. Biol. Chem. 1998, 273, 11401-11404. [CrossRef] [PubMed]

59. Lackmann, J.W.; Wende, K.; Verlackt, C.; Golda, J.; Volzke, J.; Kogelheide, F.; Held, J.; Bekeschus, S.; Bogaerts, A.; Schulz-von der Gathen, V.; et al. Chemical fingerprints of cold physical plasmas-An experimental and computational study using cysteine as tracer compound. Sci. Rep. 2018. [CrossRef] [PubMed]

60. Kasai, S.; Shiku, H.; Torisawa, Y.-s.; Noda, H.; Yoshitake, J.; Shiraishi, T.; Yasukawa, T.; Watanabe, T.; Matsue, T.; Yoshimura, T. Real-time monitoring of reactive oxygen species production during differentiation of human monocytic cell lines (THP-1). Anal. Chim. Acta 2005, 549, 14-19. [CrossRef]

61. Traore, K.; Trush, M.A.; George, M., Jr.; Spannhake, E.W.; Anderson, W.; Asseffa, A. Signal transduction of phorbol 12-myristate 13-acetate (PMA)-induced growth inhibition of human monocytic leukemia THP-1 cells is reactive oxygen dependent. Leuk. Res. 2005, 29, 863-879. [CrossRef] [PubMed]

62. Gerszten, R.E.; Garcia-Zepeda, E.A.; Lim, Y.C.; Yoshida, M.; Ding, H.A.; Gimbrone, M.A., Jr.; Luster, A.D.; Luscinskas, F.W.; Rosenzweig, A. MCP-1 and IL-8 trigger firm adhesion of monocytes to vascular endothelium under flow conditions. Nature 1999, 398, 718-723. [CrossRef] [PubMed] 
63. Camussi, G.; Deregibus, M.C.; Tetta, C. Tumor-derived microvesicles and the cancer microenvironment. Curr. Mol. Med. 2013, 13, 58-67. [CrossRef] [PubMed]

64. Fagone, P.; Di Rosa, M.; Palumbo, M.; De Gregorio, C.; Nicoletti, F.; Malaguarnera, L. Modulation of heat shock proteins during macrophage differentiation. Inflamm. Res. 2012, 61, 1131-1139. [CrossRef] [PubMed]

65. Olichon, A.; Baricault, L.; Gas, N.; Guillou, E.; Valette, A.; Belenguer, P.; Lenaers, G. Loss of OPA1 perturbates the mitochondrial inner membrane structure and integrity, leading to cytochrome c release and apoptosis. J. Biol. Chem. 2003, 278, 7743-7746. [CrossRef] [PubMed]

66. Yeo, J.-K.; Cha, S.-D.; Cho, C.-H.; Kim, S.-P.; Cho, J.-W.; Baek, W.-K.; Suh, M.-H.; Kwon, T.K.; Park, J.-W.; Suh, S.-I. Se-methylselenocysteine induces apoptosis through caspase activation and bax cleavage mediated by calpain in SKOV-3 ovarian cancer cells. Cancer Lett. 2002, 182, 83-92. [CrossRef]

67. Skinner, H.D.; Zheng, J.Z.; Fang, J.; Agani, F.; Jiang, B.H. Vascular endothelial growth factor transcriptional activation is mediated by hypoxia-inducible factor 1alpha, HDM2, and p70S6K1 in response to phosphatidylinositol 3-kinase/AKT signaling. J. Biol. Chem. 2004, 279, 45643-45651. [CrossRef] [PubMed]

68. Palm, S.; Back, T.; Claesson, I.; Danielsson, A.; Elgqvist, J.; Frost, S.; Hultborn, R.; Jensen, H.; Lindegren, S.; Jacobsson, L. Therapeutic efficacy of astatine-211-labeled trastuzumab on radioresistant SKOV-3 tumors in nude mice. Int. J. Radiat. Oncol. Biol. Phys. 2007, 69, 572-579. [CrossRef] [PubMed]

69. Hills, C.; Kelland, L.; Abel, G.; Siracky, J.; Wilson, A.; Harrap, K. Biological properties of ten human ovarian carcinoma cell lines: Calibration in vitro against four platinum complexes. Br. J. Cancer 1989, $59,527$. [CrossRef] [PubMed]

70. Olas, B.; Wachowicz, B.; Majsterek, I.; Blasiak, J. Resveratrol may reduce oxidative stress induced by platinum compounds in human plasma, blood platelets and lymphocytes. Anticancer Drugs 2005, 16, 659-665. [CrossRef] [PubMed]

71. Petru, E.; Sevin, B.U.; Perras, J.; Boike, G.; Ramos, R.; Nguyen, H.; Averette, H.E. Comparative chemosensitivity profiles in four human ovarian carcinoma cell lines measuring ATP bioluminescence. Gynecol. Oncol. 1990, 38, 155-160. [CrossRef]

(C) 2018 by the authors. Licensee MDPI, Basel, Switzerland. This article is an open access article distributed under the terms and conditions of the Creative Commons Attribution (CC BY) license (http:/ / creativecommons.org/licenses/by/4.0/). 